Egypt. J. of Nutrition and Health Vol. 16 No. 1 January (2021)

\title{
Protective Effect of Sowthistle (Sonchusoleraceus)on liver function and serum lipids in Rats intoxicated with Oxytetracycline By
}

\author{
Soheir M. El-deab ${ }^{1}$ and Huda A. Alamer ${ }^{2}$ \\ ${ }^{1}$ Assistant Professor of Nutrition and food Science ' Afif College of Science and \\ Humanities, Shaqra University, Saudi Arabia. \\ ${ }^{2}$ Associate Professor of Nutrition and food Science, Princess \\ Nourah bint Abdulrahman University, Saudi Arabia.
}

\begin{abstract}
Sowthistle is a common plant for its medicinal and nutritional benefits became widely used in several countries. This study aimed to investigate the effects of different concentrations (3\% and $6 \%)$ of Sowthistle on blood lipids in rats. Twenty-four male albino rats were used for the experiment .Rats were fed on the basal diet for a week, after that they were divided into four groups (six rats each). Group 1: Negative control group, continued feeding on the basal diet only.Group2:Positive control group continued on the basal diet during the whole experimental period and injected intraperitoneal with $(120) \mathrm{mg} / \mathrm{kg}$ of body weight of Oxytetracycline for the first three consecutive days. Group3:continued as group 2and given Sowthistle powder 3\%on the basal diet. Group4: continued as group 3 but were given 6\% Sowthistle powder. The study continued for eight weeks after the injection of Oxytetracycline. At the end of the experiment, blood samples were collected, to determine lipids profiles. The biological parameters were recorded. The study showed that diet fortified with $3 \%$ and $6 \%$ Sowthistle powder helped improving blood lipid levels in rats compared with the positive control groups (injected with oxytetracycline). Hence,Sowthistle powder helped to improve liver function and blood lipid levels in rats intoxicated with oxytetracycline.
\end{abstract}

Keywords:Blood lipids -Rats - Sowthistle - Oxytetracycline.

\section{Introduction}

Atherosclerosis is a common disease and causes over 20 million deaths all over the world. Many studies have reported that diet is the most important environmental variable affecting human metabolism (Perez. et al.; 2016).

Atherosclerosis is a chronic disease characterized by lipid deposition and inflammation in the arterial system(Anderson et al.,2017) and (Simon et al., 2019). A change in diet and other lifestyle modifications may help to reduce cholesterol levels in the blood. Avoiding animal products may help to decrease cholesterol levels in the body (Brown and Goldstein, 2018).An increased percentage of free cholesterol was associated with the evolution of the atherosclerotic process (Pillai et al., 2015) and (Lemena., 2016)showed that an increase in the percentage of free 


\section{Soheir M. El-deab and Huda A. Alamer}

cholesterol, whereas lesion caps was more enriched in cholesteryl ester.(Taleb-Senouiet al., 2017).Hypercholesterolemia refers to increased levels of blood lipids, including triglycerides and cholesterol Theyincrease the risk of coronary heart disease (CHD) and other sequelae of atherosclerosis (Emma Leah., 2014).

Tetracycline is an oral, broad-spectrum antibiotic used to treat mild-to-moderate infections due to susceptible microbial organisms. High doses of several forms of tetracycline given have been associated with acute fatty liver that can be severe and result in liver failure and death. High doses of intravenous tetracycline can induce fatty liver disease and may result in severe hepatic dysfunction, acute liver failure and death (Alexander, 2015).

Sowthistle is more common in Egypt than in Saudi Arabia, where its natural presence in Saudi Arabia depends on rain. The genus Sonchus, Species Sonchusoleraceus family Asteraceae,Kingdom Plantae, Subkingdom Tracheobionta, Division Magnoliophyta, Class Magnoliopsida, tribe Lactuceae, commonly known as Sowthistle, includes approximately 60 species with many microspecies, divided into eight sections (Abbas et al., 2015).Sowthistle(Sonchusoleraceus), is an herbal medicine used for the treatment of disorders and jaundice of the liver, gallbladder, and hepatic ailments (Yourena et al., 2013) and (Abertas et al., 2014). Conventionally, root, and herb from Sonchushave reported beingused for the treatment of various ailments, including gallbladder disorders and liver (Mahmood et al., 2015) and (Chandra,2014).

This study aimed to investigate the protective effect of Sowthistle on fatty liver in rats induced by oxytetracycline.

\section{Materials and Methods}

\section{Materials:}

Egyptian cultivar of Sowthistle was purchased from Research Institute, Ministry of Agriculture Giza, Egypt. Starch and soybean oil was purchased from a local market. Casein, vitamins, minerals,cellulose, dextrin, Cesplatin, choline chloride, and cysteine were obtained from the Cairo Company for Chemical Trading, Cairo, Egypt.

Twenty-four Sprague-Dawley Strain male albino rats weighing approximately $(160 \pm 20$ g)were used for the study. All rats fed on control diet (basal diet) for one week for adaptation in the Animal House of Ophthalmology Research Center, Giza, Egypt, of Experimental Animals, which conformed to the international ethics for handling and care of experimental animals according to the Canadian Council on Animal Care "CCAC" (1993).

Kits used to determine,ALT, AST, ALP, triglycerides, cholesterol, LDL-C produced by Egyptian American Company for laboratory service and supplied by Alkan Company..

\section{Methods:}

\section{Preparation for dried Sowthistle leaves:}

The fresh Sowthistle leaves were washed by water,then dried by cotton cloth to remove the excess water. The leaves were dried at $40^{\circ} \mathrm{C}$ by Solar Energy, and vacuum packaged until use,then leaves were ground into a powder with a mill (Lee et al., 2017). 


\section{Egypt. J. of Nutrition and Health Vol. 16 No. 1 January (2021)}

\section{Experimental design:}

Rats were fed on the basal diet (Chandra, 2014) for one week for adaptation prior, and housed in well-aerated cages under hygienic conditions. After this week, rats were divided into (4) groups, (six rats each) fed on diets for eight weeks as follows:

Group 1: Negative control group, fed on the basal diet only.

Group 2: Positive control group, injected intraperitoneal with (120) $\mathrm{mg} / \mathrm{kg}$ of body weight from Oxytetracycline for three consecutive days, and continued on the basal diet during the whole experiment.

Group 3: continued as group2 and rats were given Sowthistle powder $3 \%$ on the basal diet. Group 4: continued as group2 but rats were given $6 \%$ Sowthistle powder on the basal diet.

\section{Blood Sampling:}

Blood samples were collected from the aorta at the end of the experiment period.

Blood was left to coagulate, then centrifuged at $3000 \mathrm{rpm}$ for 15 minutes to obtain serum from each sample and then stored at $-20^{\circ} \mathrm{C}$ for laboratory analyses (Allain., 1974).

\section{Biochemical analysis of serum:}

Serum samples were used for determination of total cholesterol (Allain. 1974),HDL-C (Aviram. 2005), triglycerides (Fosaty,\&Prencipe 1982), VLDL-C and LDL-C were calculated using the method of (Lopes et al., 1977). Alanine aminotransferase (ALT), aminotransferase (AST) and alkaline phosphatase (ALP) were determined according to the method of (Allain. 1974),

\section{Statistical analysis:}

Data were statistically analyzed by using "ANOVA" according to (Berry, 1987).For all calculations the computer software system (SPSS, 2011) program, version (18) was used.

\section{Results and Discussion}

Effects of Sowthistle on liver enzymes of rats (table 1) Results indicated that positive control group injected with oxytetracycline $(120) \mathrm{mg} / \mathrm{kg}$ body weight, showed a significantly higher $(P<0.05)$ value of ALT and AST compared with the negative control group. This is due to the destructive effect of the drug on liver cells. Feeding rats on the basal diet fortified with Sowthistle powder at $3 \%$ and $6 \%$ for eight weeks caused a significant reduction in the mean values of serum Alanine transaminase (ALT) and Aspartate transaminase (AST) compared with that of the positive control group.This result agrees with (Zedan, et al., 2014) they showed that treated rats for four consecutive days of oxytetracycline caused inflammation and fatty liver,necrosis. These histological changes were associated with a higher significant increase in activities of serum AST, ALT. They attributed the significant increase may be due to a rise in free radicals that decrease the antioxidant enzyme levels. The significant decrease in ALT, AST activities in Sowthistle treated group results from the hepato-protective effect of Sowthistle (Zedan et al., 2014).

The antioxidant, anti-inflammatory and free radical scavenging property of Sowthistle have improved the effect of oxytetracycline on serum LDH activity through scavenging the free radicals; minimize lipid peroxidation, thereby preventing leakage of enzymes and membrane damage (Pillai et al., 2015) they suggested that Sowthistle might offer protection to the 


\section{Soheir M. El-deab and Huda A. Alamer}

myocardium through preventing the lipid peroxidation of membrane-bound polyunsaturated fatty acids.

Table ( 1 ):

Effect of feeding intoxicated rats with Sowthistle on serum liver enzymes

\begin{tabular}{l|c|c|c}
\hline Groups & AST $(\mathrm{u} / \mathrm{l})$ & ALT $(\mathrm{u} / \mathrm{l})$ & ALK $(\mathrm{u} / \mathrm{l})$ \\
\hline $\begin{array}{l}\text { Control (- ve) } \\
\text { Control (+ ve) Oxytetracycline injection (120 } \\
\mathrm{mg} / \mathrm{kg}\end{array}$ & $45.63 \mathrm{a} \pm 0.57$ & $33.21 \mathrm{a} \pm 2.84$ & $834.25 \mathrm{a} \pm 5.54$ \\
\hline $\begin{array}{l}\text { Control (+ ve) \& fed with basel diet }+3 \\
\text { \%Sowthistle Powder. }\end{array}$ & $52.81 \mathrm{bc} \pm 4.94$ & $38.86 \mathrm{~b} \pm 2.89$ & $849.44 \mathrm{~cd} \pm 2.06$ \\
\hline $\begin{array}{l}\text { Control (+ ve) \& fed with basel diet }+6 \\
\text { \%Sowthistle Powder. }\end{array}$ & $48.22 \mathrm{ab} \pm 2.48$ & $36.85 \mathrm{ab} \pm 1.33$ & $847.63 \mathrm{bc} \pm 6.17$ \\
\hline
\end{tabular}

Values at the same column with different letters are significantly different at $(p<0.05)$

Effect of feeding Sowthistle powder on triglyceride and total cholesterol of rats (table 2) Results in the table showed a significant rise in serum Total Cholesterol (TC) andTriglyceride (TG) of a control positive group compared with a control negative group. Feeding rats on, the basal diets containing $3 \%$ and $6 \%$ of Sowthistle induced a significant decrease $(p<0.05)$ in total cholesterol and triglyceride. These results agree with the studies conducted by (Devarajet al 2016) who showed that the diet with Sowthistle leaf lowered both levels of LDL cholesterol and triglyceride significantly. Fortified with $3 \%$ and $6 \%$ of Sowthistle caused a significantly lower in Triglyceride level than in the control group $(p<0.05)$.

Table ( 2 ):

Effect of Sowthistle powder on triglyceride and total cholesterol.

\begin{tabular}{l|c|c}
\hline \multicolumn{1}{c|}{ Parameters } & Triglyceride mg/dl & Cholesterol mg/dl \\
\hline Control (- ve) & $109.42 \mathrm{a} \pm 6.13$ & $142.62 \mathrm{a} \pm 8.60$ \\
\hline $\begin{array}{l}\text { Control(+ve)Oxytetracycline injection }(120 \\
\mathrm{mg} / \mathrm{kg})\end{array}$ & $192.20 \mathrm{e} \pm 6.08$ & $251.10 \mathrm{c} \pm 6.43$ \\
\hline $\begin{array}{l}\text { Control (+ ve) \& fed with basel diet }+3 \% \\
\text { Sowthistle powder. }\end{array}$ & $143.61 \mathrm{~d} \pm 6.37$ & $152.81 \mathrm{~b} \pm 5.42$ \\
\hline $\begin{array}{l}\text { Control (+ ve) \& fed with basel diet }+6 \% \\
\text { Sowthistle powder. }\end{array}$ & $131.21 \mathrm{c} \pm 5.62$ & $148.22 \mathrm{~b} \pm 4.80$ \\
\hline
\end{tabular}

Values at the same column with different letters are significantly different at $(p<0.05)$

Effect of feeding Sowthistle powder on low- density lipoprotein, very low- density lipoprotein and high- density lipoprotein, ( Table 3 )

Results indicated that positive control group significantly increased serum levels of lowdensity lipoprotein,very-low-density lipoprotein, and decreased the high-density lipoprotein compared with the negative control group. Rats which fed on diet supplemented with Sowthistle powder at $3 \%$ and $6 \%$ has lower mean values of very low density lipoprotein cholesterol ( VLDL-C ), and low density lipoprotein cholesterol ( LDL-C ) compared with the positive control group. All treated groups with suplemented diet at different levels of Sowthistle had higher mean values of ( HDL-C ) compared with the positive control group. This result was in agreement with( Pillai, et 


\section{Egypt. J. of Nutrition and Health Vol. 16 No. 1 January (2021)}

al., 2015) who reported that supplementation with Sowthistle leaf resulted in a significant increase in the levels of HDL. The diet with Sowthistle leaf lowered levels of LDL and triglyceride significantly (lee et al 2017). However adding of the leaf powder gave better results.

Table ( 3 ):

Effect of Sowthistle powder on ( HDL-C ), ( LDL-C ) and ( VLDL-C ).

\begin{tabular}{|c|c|c|c|}
\hline $\begin{array}{ll}\text { Groups } & \text { Parameters } \\
\end{array}$ & HDL-C mg/dl & LDL-C mg/dl & VLDL-C mg/dl \\
\hline Control (- ve) & 45.30 e \pm 2.25 & $76.31 \mathrm{a} \pm 10.22$ & $22.27 \mathrm{a} \pm 1.27$ \\
\hline $\begin{array}{l}\text { Control (+ve) Oxytetracycline injection } \\
(120 \mathrm{mg} / \mathrm{kg})\end{array}$ & $36.65 a \pm 1.52$ & $179.42 \mathrm{~d} \pm 5.92$ & 39.00 e \pm 1.08 \\
\hline $\begin{array}{l}\text { Control (+ ve) \& fed with basel diet }+3 \% \\
\text { Sowthistle powder. }\end{array}$ & 41.86bcd \pm 1.31 & $83.09 \mathrm{bc} \pm 4.63$ & $27.97 d \pm 1.24$ \\
\hline $\begin{array}{l}\text { Control (+ ve) \& fed with basel diet }+6 \% \\
\text { Sowthistle powder. }\end{array}$ & 44.23de \pm 2.39 & $78.39 \mathrm{ab} \pm 4.40$ & 25.84 c \pm 1.15 \\
\hline
\end{tabular}

Values at the same column with different letters are significantly different at $(p<0.05)$

( LDL-C ) Low density lipoprotein cholesterol.

( HDL-C ) High density lipoprotein cholesterol.

( VLDL-C ) Very density lipoprotein cholesterol.

$(p<0.05)$

\section{Conclusion}

In conclusion, considering the useful effects of Sowthistle (Sonchusoleraceus) powder helped to improve blood lipid levels in albino rats intoxicated with oxytetracycline, it might be considered as a herb with the potential of reducing liver risk factor accumulation induced by Oxytetracycline.

\section{Ethics approval and consent to participate.}

All experiments were carried out according to recommendations of the ethical conditions approved by the Ethics Committee of Ophthalmology Research Center,Giza, Egypt, of Experimental Animals, which conformed to the international ethics for handling and care of experimental animals according to the

\section{Canadian Council (1993).}




\section{References}

Abbas JA; El-Oqlah AA; Mahasneh AM, (2015):

Herbal plants in the traditional medicine of Bahrain. In: Economic botany, 46(2):158-163.

Abertas,D.; Gulfraz,M.; Ahmad,M.; Tahir,R. andAnwar,P. (2014):

Cytoprotective potential of methanolic leaves extract of Sonchusoleraceuson CCl4 induced Rats. Pensee J.; 75:220-227.

Alexander, A. F. (2015):

Oxytetracycline-associated nephrotoxicosis in feedlot calves. J. Am. Vet. Med. Assoc., 185, 793-795.

Allain, C. C.; (1974):

Enzymatic determination of total serum cholesterol.Clinical Chemistry, 20: 470-475

Anderson, K.M.; Odell, P.M.; and Kannel, W.B.;(2017):

Cardiovascular disease risk profiles. American Heart Journal 121:293-298.

Aviram, C.C. (2005):

Cholesterol determined in high denisty lipoprotein separated by three different methods. Clin. Chem.; 23 (5): 882.

Berry,G.;(1987).

Statistical methods in medical research. Distributors, USA, Year Book Medical Publishers. ISBN 631- 05258.

Brown.M.S, and Goldstein. J.L.; (2018).

Regulation of cholesterol metabolism by proteolysis of a membrane-bound transcription factor. Cell 89 (3): 331-40.

\section{Canadian Council on Animal Care "CCAC" (1993).}

Guide to the care and useof experimental animals, Ottawa Ontario Canada 1-298

Chandra SK, (2014):

Modelling the morphogenesis of annual sowthistle, a common weed in crops. American Journal of Plant Sciences, 3:177-184

Devaraj,E. (2016):

Hepatoprotective properties of Sowthistle. J. of Applied Pharmaceutical Science Vol. 6 (04), pp. 202-205.

\section{Emma Leah., S. (2014):}

High-density lipoprotein, cardiovascular disease and cholesterol. Four prospective American studies". Circulation 79 (1): 8-15. 


\section{Egypt. J. of Nutrition and Health Vol. 16 No. 1 January (2021)}

Fosaty, P. and L. Prencipe, (1982).

Determination of Serum Triglycerides Colorimetrically with an Enzyme Producing Hydrogen Peroxide. Clinical Chemistry, 28, 2076-2081.

Lee. O. Yim J. Cho C. Rhee Y. Lim S. Kim Y. Choi U., (2017).

Antioxidant Effects of Sowthistle (Sonchusoleraceus) Leaf on Cholesterol. International Journal of Molecular Sciences. 11, 67-78.

Lemena, T.Y.; Allian, C.C.; poon, L.S. and Chan, C.S. (2016): Enzymatic determination of total serum cholesterol, Clin. Chem., 20:470-475.

Lopes, M., S. Stone, S. Ellis and J. Collwell, (1977).

Cholesterol determined in high denisty lipoprotein separated by three different methods. Clin. Chem.; 23 (5): 882.

Mahmood ,M.; Ahamd,D.; Ahmad,M.; Qureshi,R.; R.; Jabeen,T. \&Abbasi,N. (2015).

Effect of leaf extracts of Sowthistle on $\mathrm{CCl} 4$ induced hepatotoxicity in rats, in vivo study. Pak J Pharm Sci; 27:825-829.

Perez, S.P.; Geraldine, F.L.; Keogh, J.G.;Garth, J.S.; cooper, H.T.; Mulvey, E.T.; Brian, G. H.; Mcardle ,U.L.; Graeme, U.W.; Dcoles, T.O.; John, G.O.; Amonro, T.E. and saly, Q.T.(2016):

Cardiovascular Disease risk facers in midly hyper cholesterolliemic men. American journal of clinical nutrition volume78, no4, 711718 .

Pillai, K; Bhandari,U.; andKanojia, R.;(2015).

Effect of ethanolic extract of Sonchusoleraceuson lipidaemia in diabetic rats, J. Ethnopharmacol. (97) 227-230.

Simon, B., J. Perez-Ilzabre, I. and Hernadez, S. (2019):

Importance of phenolic compounds for the characterization of fruit Nectars J. Agric.Food Chem., 40: 1531-1535.

Taleb-Senoui, E.O.; UffeRavnskov, R.O.; and Minehira, K. (2017): The Cholesterol Myths : Exposing the Fallacy that Saturated Fat and Cholesterol Cause Heart Disease. New Trends Publishing, Incorporated.

Yourena,Y.; Yoo,S.; Park,J.; Lee,Y.; Kim,S.; Oh,K.; Lee,J.; \&Jun,W. (2013):

Hepatoprotective effects of the aqueous extract from Sowthistle against alcohol-induced oxidative stress. Food ChemToxicol 2010; 48:1632-1637.

Zedan,G ; Abd El-Wahab,S.; Sharaf,A. and Helal,E.;. (2014):

Effect of Zingiber on fatty liver induced by oxytetracycline in rats. The Egyptian Journal of Hospital Medicine. 46( 26 ): 42-26. 


\section{الأثر الوقائي للجغضيض على وظيفة الكبا ودهنيات السيرم في الجرذان المصابين بتسمم}

$$
\text { الاوكسى تثرسيكلين }
$$

\section{سهيز محسوب احمد المنسي الديب1 و هدى احمد العامر2}

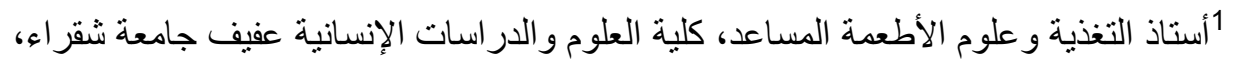
المملكة العربية السعودية.

2استاذ التغذية و علوم الأطعمة المشارك، جامعة الاميرة نوره بنت عبد الرحمن، المملكة العربية السعودية.

\section{الملخص العربي}

ينتشراستعمال نبات الجعضيض في كثير من البلدان لفائدته التغذوية والعلاجية وتهدف هذه الدراسة

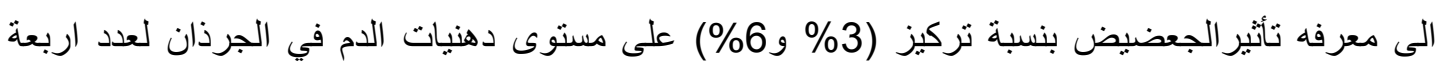

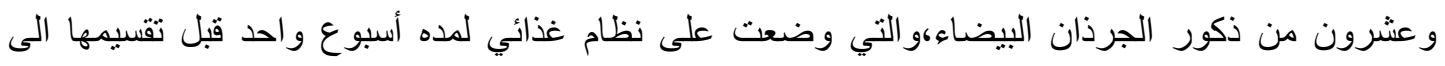

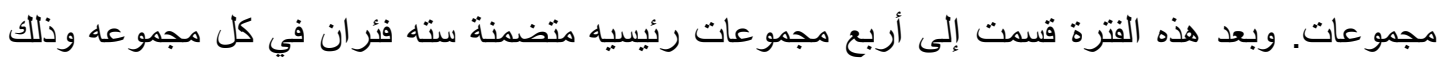
على النحو التالي:المجموعة (1):المجموعة الضابطة السالبة تغذت على على النظام الغذائي الأساسي.

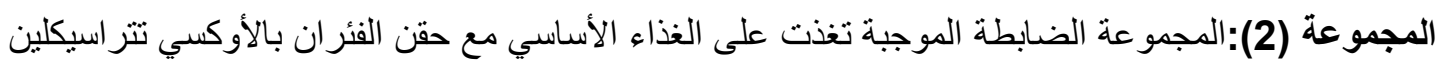

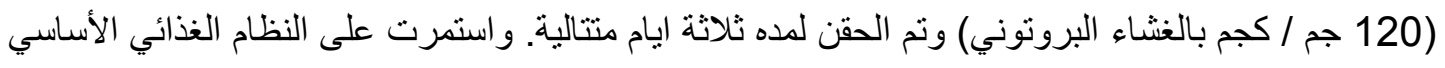

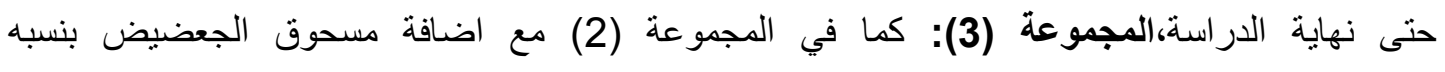

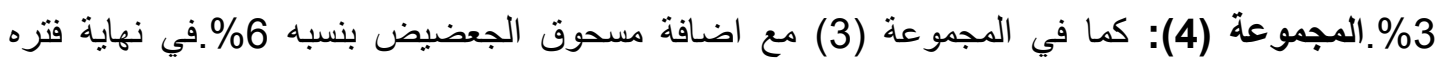

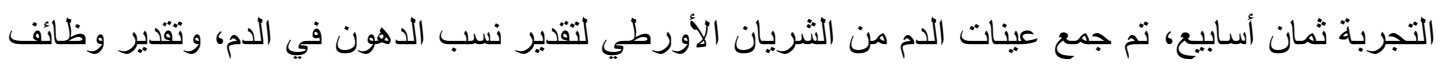

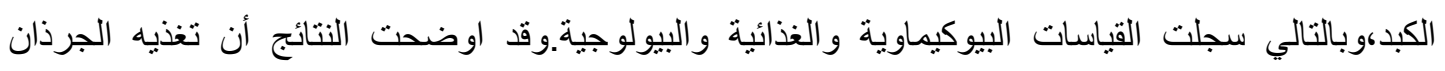

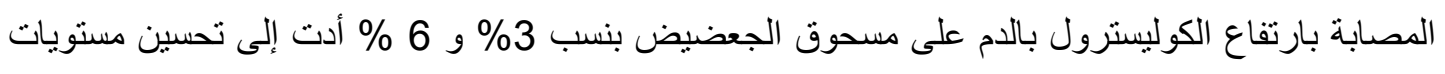

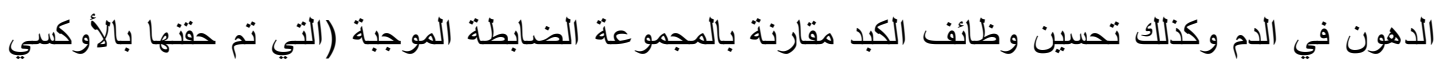
تتر اسيكلين). الكلمات المفتاحية:دهنيات الدم - جرذان - الجعضيض - أوكسي تتر اسيكلين. 